\title{
Employee Performance Management Scenarios in the Era of Work from Home
}

\author{
Taofik Hidayat ${ }^{1}$, Syamsul Maarif ${ }^{2}$, Alla Asmara ${ }^{3}$ \\ ${ }^{1,2,3}$ Graduate, IPB Business School, Indonesia. \\ Corresponding Author: Taofik Hidayat
}

DOI: https://doi.org/10.52403/ijrr.20220151

\section{ABSTRACT}

Almost all companies in the world have implemented the work from home (WFH) system in the last two years with the aim of limiting community activities in suppressing the spread of Covid-19. Interestingly, both companies and employees also feel benefited from this system, one of which for employees is that they can arrange work places and positions so that they can increase work motivation, for companies they can reduce company costs such as office rental costs. This study aims to analyze the effect of work from home on work motivation, job satisfaction and employee performance, the effect of job satisfaction on employee performance, the effect of work motivation on employee performance, and to create scenarios for managing employee performance. The study was conducted in October 2021 on 86 respondents who work at PT XYZ Jakarta, Surabaya and Medan branches. They were selected by volunteer sampling with the criteria of employees who have worked for at least one year with the level of position as supervisor and staff who have been assigned to work from home. Data were collected by distributing online questionnaires, then analyzed using descriptive analysis and SEM-PLS with the SmartPLS application and TAIDA analysis to determine managerial implications. The results showed that Work from Home had a direct and positive significant effect on Work Motivation and Job Satisfaction but not significant on Employee Performance, Job Satisfaction had a direct and positive effect on Employee Performance, and Work Motivation had no direct effect on Employee Performance. The form of managerial implications that can be carried out for managing employee performance
\end{abstract}

is by using a hybrid work system, namely employees can work with a mixed system between work from home and work in the office.

Keywords: job satisfaction, employee

performance, work motivation, work from home

\section{INTRODUCTION}

Several steps taken by the government to reduce the rate of spread of covid-19 have been carried out such as a large-scale social restriction system, as well as the enactment of restrictions on community activities level-1 to level-4. The goal is to limit community activities or social distancing so that the spread of covid19 does not reach widespread. Work from home (WFH) is one of the methods used to apply social distancing.

Work from home activities for some companies in the world have been widely done, this is to anticipate the pace of urbanization, reduce congestion levels and lower employee stress levels during commuting and returning to work. In addition, some of the advantages of work from home for employees, including can save accommodation costs and more flexible working hours. According to Timbal and Mustabsat (2016), companies that implement work from home systems prove that with work from home productivity becomes higher.

Currently, PT XYZ has been doing a work from home work system for more than one year, based on productivity figures in the last three years, in 2020 only slightly 
decreased due to declining sales, but in 2021 it has increased (Figure 1), this is certainly an opportunity for companies to continue to do the work from home system. It's in the future. Therefore, if it needs to be studied more deeply about the further influence of this work from home system to then be a reference base in the management of employee performance in the company, not only meet the government's obligations in overcoming pandemics, but also an alternative solution for companies to remain competitive in the economic market.

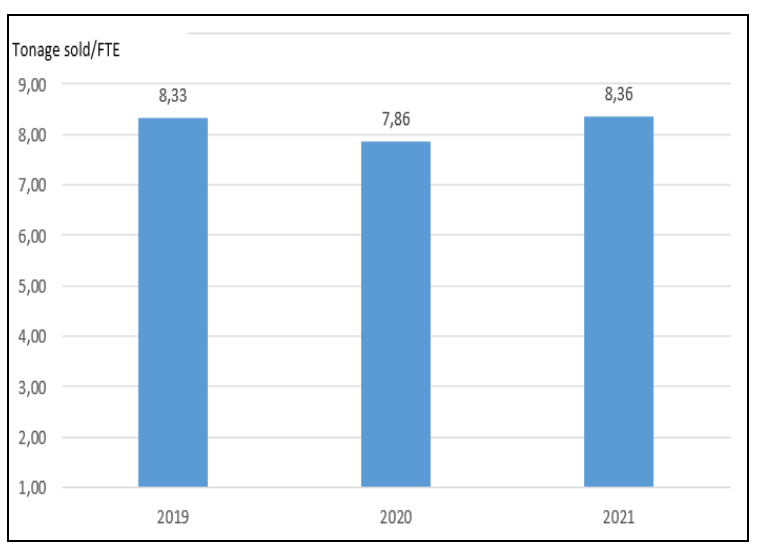

Figure 1: Productivity of PT XYZ employees

With some of the information above can be done more research on the work from home work system to prove how it affects performance, motivation and job satisfaction. Performance is one of the benchmarks for a company can be categorized as a competitive company or not, a competitive company is a company that has good employee performance, as well as employee motivation and job satisfaction whether the enactment of this system can improve the employee job satisfaction and work motivation, as well as how the scenario of managing employee performance in this work from home era. Against this background, the formulation of the problems that will be studied in this study is:

1. How does the work from home affect employee performance, job satisfaction, and employee work motivation?

2. How does job satisfaction affect employee performance?
3. How does work motivation affect employee performance?

4. What is the scenario of managing the performance of PT XYZ employees in the era of work from home?

Referring to the background and formulation of the problem, the purpose of this study is to test and (1) Analyze the effect of work from home on employee performance, job satisfaction, and employee work motivation (2) Analyze the effect of job satisfaction on employee performance (3) Analyze the influence of work motivation on employee performance, and (4) Formulate an employee performance management scenario at PT XYZ.

\section{LITERATURE REVIEW Work from Home}

Work from home (WFH) is a term for working remotely or remote working, meaning doing work from home for work that is commonly done in the office. The work from home system is part of a concept of working remotely or telecommuting, this concept is not new in the world of work and urban planning, since the 1970s this concept has been known as one of the efforts in overcoming traffic congestion caused by commuting activities every day home trips to the office and vice versa (Mungkasa, 2020). In the current pandemic era work from home is a trend in the work system, where almost all companies have to apply it to reduce the rate of spread of covid-19.

Developed countries already use this remote work system with the term telecommuter. Telecommuters have the ability to modify and customize their own work environment so as to improve their work performance. Working outside the office can also eliminate the costs and time that employees have to spend to work; it also creates a feeling of freedom that makes employees satisfied so that it affects their performance (Gajendran \& Harrison, 2007). In line with previous opinions, Caillier (2016) states that workers who do remote work at a higher rate tend to have better work motivation than those who do not. 


\section{Job Satisfaction}

According to Handoko (1994), job satisfaction is a state where employees view their work as emotionally pleasing. This thing reflects a person's feelings towards his work. The employee's positive embrace of the job and everything encountered in his work environment will appear visible. The satisfaction that an employee has for a job that he is experiencing, will make the employee always do his best to do his job.

Job satisfaction becomes a fairly important element in the organization because it can affect work behavior such as diligent or lazy. A person's job satisfaction is influenced by many factors, such as salary level, boss, co-workers and the compatibility between work expectations and the reality they encounter and get from work.

\section{Motivation for work}

Motivation is the impulse that arises in a person consciously or unconsciously to perform an action with a specific purpose or efforts that cause a person or a certain group of people to move to do something because they want to achieve the desired goal or get satisfaction for his actions (KKBI). According to Rivai et al. (2005) is a set of attitudes and values that influence individuals to achieve specific things according to individual goals. These attitudes and values are invisible that give the power to encourage individuals to behave in achieving goals.

Motivation theory is divided into two, namely theory that focuses on processes and motivation theory focuses on needs (Cinintya 2019). In this study uses a theory of motivation that focuses on needs. Some motivation theories that focus on need include Maslow's hierarchy theory, Alderfer's Existence Relatedness Growth (ERG) theory, and Herzberg's two-factor theory.

\section{Employee Performance}

In the behavioral approach to management, performance is defined as the quality produced or the services provided by someone who does the job (Luthans 2005). Performance itself comes from the word job performance or actual performance which means work performance or actual achievement achieved by someone. Performance becomes a very important element in the organization because it is often used as a benchmark for success in the implementation of an organization.

An organization can be categorized as high performer if it can successfully exceed its goals, and can provide positive value for the environment and society. Employee performance can be categorized as high if the employee can work productively, creatively and efficiently.

\section{METHODS}

Research design uses quantitative and qualitative approaches. Quantitative approach by conducting an online survey of employees of PT. XYZ, then for qualitative approach conducted in-depth interview method with the management. Data collection was conducted in October 2021, with samples spread across Jakarta, Surabaya and Medan.

Pengambilan sample used non probability sampling technique with quota sampling technique. The sample from this study is an employee of PT. XYZ, with a population of 108 people, based on the formula Slovin then the number of examples used for 86 people. Regulars who have worked from home during the covid-19 pandemic from supervisor to implementer level and worked for more than a year were sample criteria in the study.

The study used descriptive analysis with methods of average scores and percentages covering gender, age, education, job level, and working span. The data obtained from the research is presented in the form of a table. Furthermore, the data is analyzed using the Structural Equation Modelling (SEM) method with the help of SmartPLS applications.

The next data analysis is TAIDA analysis which stands for Tracking, Analyzing, Imaging, Deciding, and Acting 
(Lindgren and Baldhood, 2003); this method is used to devise steps in scenario planning.

There are dependent variables, independent variables and intervening variables in this study. Kinerja employees are variabel dependent, independent variables that work from home; intervening variables are job satisfaction and work motivation. The work from home variable consists of three dimensions, namely the dimensions of space, time and social roles (Gadecki, 2018), the work satisfaction variable consists of five dimensions namely payment, work, promotion, supervisor, and colleagues (Sopiah, 2008), work motivation variable consists of three dimensions namely existence, relatedness, and growth (Siagian, 2008) and employee performance variable consists of six dimensions namely quantity, quality, punctuality, effectiveness, self-sufficient and work commitment (Bernardin \& Russell, 1993).

The hypotheses that will be tested in this study are:

H1: work from home has a real effect on employee performance

Based on the results of Susilo's research (2020), it was produced that by working from home, employees experience greater enjoyment, satisfaction and motivation so as to improve performance. As well as supported by Nasution, et al. (2021) who explained that the relationship of work from home with employee performance has a strong relationship and a positive pattern.

H2: work from home has a real effect on job satisfaction

Sriyaningsih et al. (2021), which proves that work from home has a positive effect on job satisfaction.

H3: work from home has a real effect on work motivation

Based on the results of research Pristiyono et al. (2020), proving that work from home has a direct and significant effect on work motivation.

H4: Job satisfaction has a real effect on employee performance

Based on indrawati research (2013) which concluded that job satisfaction has a significant positive influence on employee performance.

H5: Work motivation has a real effect on performance

Based on the results of Hanafi \& Yohana (2017), as well as Asim (2013) research that concluded that motivation has a real effect on employee performance.

\section{RESULTS}

Table 1: Demographic characteristics of respondents \begin{tabular}{|l|l|l} 
Characteristic & Number (n) & Percentage (\%)
\end{tabular} Gender

\begin{tabular}{|c|c|c|c|}
\hline$\bullet$ & Man & 49 & 57 \\
\hline$\bullet$ & Woman & 37 & 43 \\
\hline \multicolumn{4}{|c|}{ Age } \\
\hline$\bullet$ & 20-30 years & 26 & 30 \\
\hline$\bullet$ & $31-40$ years & 47 & 55 \\
\hline$\bullet$ & $>40$ years & 13 & 15 \\
\hline \multicolumn{4}{|c|}{ Education } \\
\hline$\bullet$ & SMA/SMK & 3 & 3 \\
\hline$\bullet$ & Diploma & 16 & 19 \\
\hline$\bullet$ & Bachelor & 64 & 74 \\
\hline$\bullet$ & Postgraduate & 3 & 3 \\
\hline \multicolumn{4}{|c|}{ Department Level } \\
\hline & Staff & 35 & 41 \\
\hline$\bullet$ & Supervisor & 51 & 59 \\
\hline \multicolumn{4}{|c|}{ Working Time } \\
\hline$\bullet$ & $1-5$ years & 41 & 48 \\
\hline$\bullet$ & $6-10$ years & 25 & 31 \\
\hline$\bullet$ & $11-15$ years & 11 & 13 \\
\hline$\bullet$ & $16-20$ years & 6 & 7 \\
\hline & $>20$ years & 1 & 1 \\
\hline
\end{tabular}

From the 86 respondents, male gender dominated, with 49 respondents (57\%), the age of the largest respondents in the range of $31-40$ as many as 47 respondents $(55 \%)$. From the age range shows that PT XYZ currently has productive human resources and is at work. The majority of respondents' education levels are strata one as many as 64 respondents (74\%), while for the level of mayoriras position is supervisor as many as 51 respondents $(59 \%)$. In the span of the majority of working hours with a working period of 1-5 years became the most, which is 41 respondents $(48 \%)$. PT XYZ is a company that has been established for more than forty years, for supervisory and implementing/staff level employees dominated by young employees who replace employees who have passed retirement. The demographic characteristics of respondents are presented in Table 1. 
The largest contribution of dimension to the work from home variable is the social role. The largest contribution of dimensions to the job satisfaction variable is the supervisor. The largest contribution of dimensions to work motivation variables is existence. The largest contribution of dimensions to employee performance variables is work commitment. Dimensional contribution data to latent variables is presented in Table 2.

From the 86 respondents, male gender dominated, with 49 respondents $(57 \%)$, the age of the largest respondents in the range of $31-40$ as many as 47 respondents $(55 \%)$. From the age range shows that PT XYZ currently has productive human resources and is at work. The majority of respondents' education levels are strata one as many as 64 respondents $(74 \%)$, while for the level of mayoriras position is supervisor as many as 51 respondents $(59 \%)$. In the span of the majority of working hours with a working period of 1-5 years became the most, which is 41 respondents (48\%). PT XYZ is a company that has been established for more than forty years, for supervisory and implementing/staff level employees dominated by young employees who replace employees who have passed retirement. The demographic characteristics of respondents are presented in Table 1.

Table 2: Dimensional contributions to latent variables

\begin{tabular}{|l|l|c|}
\hline \multicolumn{1}{|c|}{ Variable } & \multicolumn{1}{|c|}{ Dimension } & $\begin{array}{c}\text { Loading } \\
\text { factor }\end{array}$ \\
\hline Work From Home & Room & 0,861 \\
\hline & Time & 0,850 \\
\hline & Social Role & 0,869 \\
\hline & Payment & 0,652 \\
\hline & Work & 0,728 \\
\hline & Promotion & 0,462 \\
\hline & Supervisor & 0,760 \\
\hline & Co workers & 0,743 \\
\hline Motivation for work & Existence & 0,883 \\
\hline & Relatedness & 0,831 \\
\hline & Growth & 0,844 \\
\hline Employee Performance & Quality & 0,742 \\
\hline & Quantity & 0,819 \\
\hline & Timeliness & 0,560 \\
\hline & Effectiveness & 0,850 \\
\hline & Independence & 0,825 \\
\hline & Work Commitment & 0,876 \\
\hline
\end{tabular}

Track coefficient and t-count tests on structural equation models are performed to test hypotheses. If the path coefficient value $>0.05$ and the $t$-count value $>1.96$ then the influence between variables falls into a significant category. More can be seen in Table 3, Table 4.

Table 3: Results of path coefficients and tests of direct influences between latent variables

\begin{tabular}{|l|c|c|c|c|}
\hline \multicolumn{1}{|c|}{ Line } & Path Coefficient & t-count & Conclusion & Information \\
\hline Work From Home -> Employee Performance & 0,157 & 1,583 & Insignificant & Rejected H1 \\
\hline Work From Home - > Job Satisfaction & 0,417 & 3,238 & Significant & Received H2 \\
\hline Work From Home - > Motivation & 0,275 & 2,469 & Significant & Accepted H3 \\
\hline Job Satisfaction - > Employee Performance & 0,584 & 3,672 & Significant & Received H4 \\
\hline Work Motivation - > Employee Performance & 0,132 & 0,885 & Insignificant & Rejected H5 \\
\hline
\end{tabular}

In Table 3 it can be known that the first hypothesis (H1) regarding the effect of work from home on performance has insignificant results with a path coefficient value of 0.157 and a t-count value of 1.583 so that the first hypothesis is rejected. Furthermore, in the second hypothesis (H2) the third hypothesis (H3) and the fourth hypothesis (H4) with a path coefficient value above 0.05 and a t-calculated value above 1.96 maka these three hypotheses are accepted. The fifth hypothesis (H5) that is the effect of work motivation on employee performance is also insignificant because the t-count value is below 1.96 so the fifth hypothesis is rejected.

Table 4: Results of path coefficients and indirect influence tests between latent variables

\begin{tabular}{|} 
Table 4: Results of path coefficients and indirect influence tests between latent variables \\
\begin{tabular}{|c|c|c|c|}
\hline Line & Path Coefficient & t-count & Conclusion \\
\hline Work From Home -> Job Satisfaction -> Employee Performance & 0,244 & 2,242 & Significant \\
\hline Work From Home - > Work Motivation -> Employee Performance & 0,036 & 0,726 & Insignificant \\
\hline Total Effect & & & \\
\hline Work From Home -> Employee Performance & 0,28 & 2,658 & Significant \\
\hline
\end{tabular}
\end{tabular}

In Table 4 it can be known that work from home has a significant effect on employee performance with job satisfaction as an intervening variable with a path coefficient value above 0.05 and a t-count value above 1.96. Furthermore, it can also 
be seen that the influence of work from home on employee performance with work motivation as an intervening variable has an insignificant effect with a path coefficient value below 0.05 and a t-count value below 1.96.

There are four proposed scenarios based on the results of TAIDA analysis, namely; (1) the first scenario, the company facilitates and the employee supports. Merupakan optimistic scenario (best), where the factors of the company and employees support the development of performance management scenarios in the era of work from home. In this scenario, the employee is arranged in such a way that some work at home and some work in the office. Of course, taking into account various aspects such as positions, work locations, workspace arrangements, compensation and benefit analysis and technology application development.(2) scenario both, the employee supports and the company does not facilitate. In this scenario there is a biased inequality factor because after all employees must follow according to the direction of the company. This scenario proposes a full work from home system meaning that the work system is done with a remote system, and no one works in the office. For IT-based start-up companies (Information Technology) this is very possible, but for the type of building materials companies such as PT. XYZ is very difficult. (3) third scenario, the company facilitates and the employee parties are less supportive. In the third scenario is still a good scenario planning, because it can still be controlled. In this scenario, a full working system works in the office as it did before the pandemic. This can be done if pandemic conditions are declared over and return to a normal situation. (4) the fourth scenario, the company does not facilitate and the employee does not support. In this scenario it is predicted that pandemic conditions will not improve so that it will have an impact on business processes, resulting in employee reductions. Of the four proposed planning kenarios, this scenario is the worst-case scenario for its impact, both on the company and the employee.

From this study obtained data that employee performance is not significantly affected by Work from home. Dapat means that directly the work from home work system does not affect the performance of PT XYZ employees. In other words, the level of employee performance cannot be measured from work from home. But companies still need to pay attention to this work from home work system, because this work system must still be run during the covid-19 pandemic still, and as long as the government has not determined that this pandemic is over and can return to work normally. The results of this study do not support Susilo's research (2020) which proves that employee performance is significantly affected by work from home.

Work from home has a positive and significant effect on job satisfaction, which means that with a good work from home system it will lead to job satisfaction. During the pandemic PT XYZ always pay attention to wage payments that are always on time, the company always pays attention to its employees by providing burdens according to employee conditions, and the promotion system that is run is also perceived by employees has been running well. From the supervisor factor and coworker support is also very supportive of employees during work from home. The results of the study in accordance with the first research study by Sriyaningsih (2021) conducted on 78 respondents explained that the work from home variable has a significant influence on employee job satisfaction.

The influence of work from home also significantly affects work motivation. One indicator that has a strong contribution to describe the variables of work motivation, namely the company statement considers the importance of the existence of employees when working at home. This means that with the application of good work from home makes employee work 
motivation increase. The results of this study are in line with research conducted by Pristiyono et al (2020) with the results that work from home has a significant influence in influencing employee motivation. This indicates that the better the work from home system managed by the company, the higher the employee's work motivation.

Employee performance variables are also significantly affected by work satisfaction. During work from home employee job satisfaction increases as previously delivered, and this job satisfaction encourages employees to increase their performance. This is in accordance with the results of research conducted by Indrawati (2013) which states that job satisfaction has a positive and significant effect in affecting employee performance. These findings are in line with other studies conducted by Triemiaty (2019) which showed that employee performance is significantly affected by job satisfaction variables.

This study proves that work activation does not have a significant influence on the performance variables of karyawan. These results do not support hanafi\&yohana research (2017) which states that work motivation has a positive and significant influence on employee performance. Pt XYZ employees are currently doing well even though the motivation has not been seen significantly, meaning if the company can optimize in increasing motivation. Employees will further improve employee performance; this can be seen from employee productivity data that does not decrease even when working in pandemic conditions.

The first scenario choice of TAIDA analysis can be taken as the most suitable lternative to choose from at this time by implementing a hybrid working system. Because this is more flexible and acceptable to both parties and in accordance with the current conditions. Furthermore, at the stage of strategy implementation in the management of employee performance through a hybrid work system, following steps need to be taken;

a. Determine which positions will be set for hybrid work.

b. Determine the employee's work location.

c. Determine the concept of workspace, namely coworking space, dedicated desk, cubical and closed room. Coworking space is a workspace that can be used by positions whose work is hybrid (can be done in the office or outside the office) or remote (entirely outside the office). This workspace can be used by co working employees who have needs and must be in the office. Dedicated desk is a desk used by employees who regularly come to the office. A workspace that has been dedicated to one employee cannot be moved for use by another employee. Cubical is a workspace that has a barrier for certain positions that are confidential such as the section related to employee salary data such as payroll, and the last closed room specifically for the board level.

d. To analyze compensation and benefits, for employees assigned with a hybrid system will certainly have different compensation. Transportation benefits are only given to coworking (sales) and dedicated employees because they are considered to still require transportation costs to the office or visit business partners and stores. Internet credit allowance is only given to coworking employees (non-sales) because they work outside the office (home) and do not get internet facilities from the office. As for the allowance of eating and communication there is no change, it is still given as is.

e. And lastly is the application of technology applications to facilitate new work systems, namely with the use of Human Resources Information System features that have been integrated with the system of absenteeism, payroll, performance assessment and employee development.

\section{CONCLUSION}

Of the five hypotheses tested, three hypotheses were accepted, namely the 
influence of work from home on job satisfaction, the influence of work from home work motivation and the influence of job satisfaction on employee performance. Two hypotheses are rejected, namely the influence of work from home on employee performance and the influence of work motivation on employee performance.

Of the two indirect lines of influence, only one path has a significant effect, namely the influence of work from home on employee performance mediated by job satisfaction. This means that job satisfaction becomes a mediator variable of work from home in affecting employee performance. While work motivation does not become a mediator variable work from home variables in affecting employee performance. In total the sum of direct and indirect influences, for the influence of work from home on employee performance is significant, which means work from home will have a significant effect if there are other variables that affect it.

One of the scenarios of managing employee performance that can be applied by the company in this work from home era is to implement a work system hybrid which is a work system that combines work from home, co-working and on-site systems. With this strategy will be more easily accepted by both employees and companies.

In implementing a hybrid work system, an assessment is needed to be made into the company about system readiness, infrastructure and employee readiness so that it can run well.

The scope of this study is limited to the influence of work from home on job motivation, job satisfaction and employee performance. The results of this study are more directed to companies with office work systems with non-shift work systems as well as parts of work that are not related to production that must operate for 24 hours.

Further research advice can conduct a study of the impact of work from home on other factors such as work life balance, where with the work from home work system can cause employees to feel exhausted because there is no barrier between office work and daily home activities.

\section{Acknowledgement: None}

Conflict of Interest: None

\section{Source of Funding: None}

\section{REFERENCES}

1. Alderfer C. 1989. Theories reflecting my personal experience and life dent. The Journal of Applied Behavioral Science.25 (4):351351.

2. Ania, H. 2018. The influence of training and motivation on the performance of EMPLOYEES of PT Asuransi XYZ. [Thesis]. Bogor: Bogor Agricultural Institute.

3. Asim M. 2013. Impact of motivation on employee performance with effect of training: specific to education sector Pakistan. International Journal of Scientific and Research Publications. 9(3): 255-261.

4. Augusty T, Ferdinand A. 2006. Structural Equation Modeling in Management Research. Semarang (ID):Diponegoro University Issuing Agency

5. Bernardin JH, Russell JEA. 1993. Human Resource Management: An Experiental Approach. Jakarta: Gramedia Pustaka

6. Boyatzis, R. E. (2008). Competencies in the 21 st century. Journal of Management Development, 27(1), 5-12.

7. Caillier, J. G. (2016). Do Teleworkers Possess Higher Levels of Public Service Motivation?.Journal Public Organization Review, 16(4), 461-476.

8. Gądecki, J., Jewdokimow, M., \& Żadkowska, M. (2018). New technologies and family life in the context of work at home. The strategies of work-life balance. Studia Humanistyczne $\mathrm{AGH}, 17(4), 77$

9. Gajendran, R. S., \& Harrison, D. A. (2007). The good, the bad, and the unknown about telecommuting: Meta-analysis of psychological mediators and individual consequences. Journal of applied psychology, 92(6); 1524.

10. Hanafi BD \& Yohana C. 2017. The influence of motivation, and the work environment, on employee performance, with job satisfaction as a mediation variable on ptbnilifeinsurance. Journal of Economic and Business Education. $5(1) ; 73-89$

11. Handoko TH. 1994. Management. Edition 2. Yogyakarta (ID): BPFE. 
12. Indrawati, A.D. 2013. The effect of job satisfaction on employee performance and customer satisfaction at private hospitals in denpasar city. Journal of Management, Business Strategy, and Entrepreneurship. 7 (2);135-142

13. Ligdgren, Mats; Bandhold, Hans. (2003). Scenario Planning: The Link Between Future and Strategy. Palgrave Machmillan: Hampshire

14. Luthans F. 2005. Organizational Behavior. New York (US): McGraw-Hill.

15. Malik ME, Danish RQ, Usman A. 2010. Impact Of Motivation To Learn And Job Attitudes On Organizational Learning Culture In A Public Service Organization Of Pakistan. African Journal of Business Management. 5(3):884-854.

16. Mangkunegara, AP. 2002. HR Management. Bandung (ID): Rosdakarya teenager.

17. Mangkuprawira S, Hubeis AV. 2007. Human Resource Quality Management. Jakarta (ID): Ghalia Indonesia.

18. Masrukhin and Waridin. 2004. Influence of Work Motivation, Job Satisfaction, Organizational Culture and Leadership on Employee Performance. EKOBIS. 7(2);197209.

19. Monroe, RW \&Haug JC. 2021. Assessment of Telework in a Federal Agency at the Operational Phase. Journal of Public Organization Review

20. Mungkasa O. 2020. Working From Home (WFH): Towards a New Order of the COVID 19 Pandemic Era. The Indonesian Journal of Development Planning. 3(2);127-128.

21. Nasution, I, Zulhendry and Rosanti, R. 2021. The influence of working from home (work from home) on the performance of BPKP employees. Scientific Journal of Accounting Budgeting. 1(1);9-14

22. Pristiyono, Ikhlash, M. Rafika, M. and Hasibuan D.K. 2020. Implementation of work from home to the motivation and performance of lecturers in Indonesia. Journal of Accounting, Economics and Business Management.8(2);263-269

23. Raziq, A \&Maulabakhsh, R. (2015). Impact of work environment on job satisfaction. Procedia Economics and Finance 23: 717725.
24. Rivai, Vethzal, Basri. 2005. Performance Appraisal: The Right System for Assessing Employee Performance and Improving Company Competitiveness. Jakarta (ID): PT Raja GrafindoPersada.

25. Riwidikdo H. 2013. Health Statistics (With SPSS Application in Research Procedures). Yogyakarta (ID): Rohima Press.

26. Robbins S. 1996. Organizational Behavior: Concepts, Controversies, Applications. Alih Bahasa HadyanaPujaatmaka. Jakarta (ID).

27. Sanuddin FDP, Widjojo AMR. 2013. Effect of job satisfaction and work motivation on the performance of EMPLOYEES of PT Semen Tonasa. ISSN. 25(2):217-231.

28. Sopiah. 2008. Organizational Behavior. Yogyakarta (ID): Andi.

29. Sriyaningsih. 2021. Analysis of the influence of work from home and the use of information technology on employee performance through job satisfaction as intervening variables. [Thesis]. Jember: Muhamadiyah University of Jember

30. Sumarwan U. 2011. Consumer Behavior: Theory and Its Application in Marketing. Bogor (ID): Ghalia Indonesia.

31. Susilo D. 2020. Revealing the Effect of WorkFrom-Home on Job Performance during the Covid-19 Crisis:Empirical Evidence from Indonesia. Journal of Contemporary Issues in Business and Government 26(1); 23 - 40

32. Thompson L.L. 2008. Organizational Behavior Today. New Jersey: Pearson Education International.

33. Timbal, A. and Mustabsat, A. (2016). Flexibility or Ethical Dilemmas: A Review of Work from Home Policy in Modern Organizations Around the World, The Essence of International Human Resource Management, 24(7)

34. Triemiaty, Maarif, M.S., Affandi, M.J., Pawenary. 2019. Employee performance improvement strategy at construction companies. Journal of Business Applications and Management. 4(1);54-68.

How to cite this article: Hidayat T, Maarif S, Asmara A. Employee performance management scenarios in the era of work from home. International Journal of Research and Review. 2022; 9(1): 452-460. DOI: https://doi.org/ 10.52403/ijrr.20220151 